\title{
A NUCLEAR TEST FOR DIPLOMACY: IRAN AND THE (NEW) EU-US SANCTIONS DEBATE
}

\section{Ioana CONSTANTIN-BERCEAN, PhD candidate}

Faculty of European Studies, Babeș-Bolyai University, Romania ioananeliabercean@gmail.com

\begin{abstract}
Europe and Iran have had important political, cultural and commercial relations that date back several centuries, but these relations have been steadily strained since 2002 when the uncertainty with regard to Iran's nuclear program became an issue of international concern. In the attempt to demonstrate its role as an important foreign policy actor capable of taking the lead in resolving a global crisis, through the leadership of France, United Kingdom and Germany (EU3) the European Union spearheaded efforts to obtain a solution to the deadlock between Tehran and the international community over Iran's nuclear program. Nowadays, after the nuclear agreement with Iran was sealed, the EU can move beyond its exclusive nuclear focus with Iran, and shift to a relationship based on engagement, not containment. However, this goal encounters an unforeseen obstacle: the new American Administration, who wants to shift the US policy on Iran toward aggressive containment and away from the diplomatic openings created by the precedent one. Therefore, it looks that the divide between Europe and the US is set to deepen over Iran, as long as the Trump Administration's heated rhetoric and actions will continue. The EU made it clear, through its High Representative for Foreign Affairs and Security Policy statements that it will continue to support the Joint Comprehensive Plan of Action. Furthermore, the European leaders understood that a constructive relationship between Iran and the EU is essential for the latter, and it could help to achieve its common security and defense objectives while safeguarding its commercial and energy interests. This article aims to present the relation between Europe Union and Iran post-JCPOA and the European agenda on Iran and to explain how and whether the nuclear agreement could become the reason of a European-American cleavage.
\end{abstract}

Keywords: European Union, Iran, Constructive Engagement, Nuclear Deal/JCPOA, European Union Global Strategy.

\section{Introduction}

Few international challenges seem quite as intractable as the continuing dispute between the Islamic Republic of Iran and the international community over the development and the direction of Iran's nuclear program. While relations between Washington and Tehran remained subject to 
mutual hostility, the European Union constituted a channel of communication since 2003, and has maintained a multilateral negotiation framework and followed a policy of constructive engagement toward Iran. The EU-3 - France, the United Kingdom, and Germany - have spent considerable political capital in finding a diplomatic solution to Iran's nuclear ambitions. During the 12 years of negotiations with Iran, the EU's role went to several phases: if in 2003 the EU-3 began as a unified and autonomous negotiator and in 2015 it had become a more pragmatic facilitator between Washington and Tehran. However, it seems that Donald Trump's administration is not one to easily get along with it, and on many global security issues, the EU's leaders had very different approaches than the American president. But perhaps nowhere the difference is more profound than on the Iranian issue. Given the president's harsh rhetoric and his decision to leave the Joint Comprehensive Plan of Action (JCPOA), announced on May $8^{\text {th }}$, 2018, a transatlantic clash over this file seems almost inevitable. However, the question is not one between saving the JCPOA and siding or not with the US, rather is one deciding what the EU's interests at stake are, and which is the best option in order to pursue them. These interests have not changed much since 2003 when the EU-3 states embarked on high-level diplomacy with Iran against the backdrop of the US invasion in Iraq. At the time, the EU was following three main purposes: to prevent the ascendance of an allegedly nuclear Iran, to avoid another war in the already tormented region and to prove its own role as a global player. By adding the issue of European energetic security to this list, so the EU can escape Russia's gas monopoly, one can see the entire picture of the European interests in preserving the JCPOA.

While Donald Trump firmly condemned the Iranian regime and referred to the nuclear agreement as being an "embarrassment" (Trump, 2017: https://www.whitehouse.gov/briefingsstatements/remarks-president-trump-iran-strategy/), the other parties of the JCPOA are firmly behind it. French President Emmanuel Macron and German Chancellor Angela Merkel vigorously lobbied President Donald Trump to remain in the agreement during their visits to Washington on the week of April 23, 2018, and the British Foreign Minister Boris Johnson made a similar appeal as the deadline of the withdrawal announcement was approaching. Also, shortly after Donald Trump's decision, the EU-3/EU leaders issued a joint statement expressing "regret" (Katzam, Kerr, Heitshusen, 2018: 3) over the American President's decision. European leaders stated that they remained committed to the JCPOA because it is "important for our joint security" (Ibid.) and the European diplomats have consistently asserted that the JCPOA is a binding international 
commitment under United Nation Security Council Resolution 2231 (2015), which endorsed the agreement. The European reaction appeared to reflect disappointment in the failure of their efforts to address President Trump's concerns through a supplemental agreement or pledges of joint action. Moreover, the European stance on safeguarding the JCPOA is complying with the provisions of the 2016 European Union Global Strategy - a substantial document with many complex dimensions, released only a few days after the June 2016 Brexit referendum - which argues that diplomacy is one of the clear strengths of the EU.

Every time when the EU undertakes a strategy-defining exercise related to some aspect of foreign policy, the core question is how to balance interests and values. If during the Cold War Western Europe yielded its interests almost exclusively to the United States in exchange for security guarantees and for a junior role in the partnership that ran the world, nowadays the EU is looking to affirm itself as a major global power. As paradoxical as it may seem, Donald Trump's decision to withdraw the United States from the JCPOA might be a real opportunity for the EU to assert itself as a major global player. However, the question is whether the EU is ready to take a stand in front of the US because preserving the JCPOA could cause fallout of the transatlantic relationship.

The US withdrawal from the nuclear agreement comes as the latest in a series of flashpoints in the EU-US relationship, following the US departure from the Paris climate agreement, giving up the Transatlantic Trade and Investment Partnership, President Trump's frosty meetings with a number of European leaders or repeated public criticism over European defense spending levels. Even if the Europeans spent much of 2017 and 2018 trying to convince Donald Trump to keep the JCPOA in place, at this point Washington's policy trajectory on the nuclear agreement is clearly at odds with the European interests, and the divide between the EU and the US is set to deepen. Moreover, in opposing Trump's policy toward Iran, the European governments find themselves in the unusual position of being closer to Russia and China than to their traditional transatlantic partner.

Drawing from all the above-presented circumstances it is easy to conclude that the sanctions debate is, once again, in full bloom. However, the question Do sanctions work? is hardly new, and once the nuclear agreement in place is obvious that the European member states (at least most of them) are looking to keep the JCPOA in place, and work on it further on. A failed diplomacy might leave the international system with a choice between the use of force or a world where restraint 
has been eroded by the inability or unwillingness of some important actors to keep their end of the bargain.

During the 2016 presidential campaign, Donald Trump was a vocal critic of the agreement. At times, he pledged to seek to renegotiate it, to strictly enforce its terms on Iran, or to abrogate it outright (Nicoullaud, 2016). The JCPOA does not contain a provision for any party to end the agreement; nevertheless, the President could decide to stop implementing some or all of the U.S. commitments in the deal, but doing so leaves open the possibility for the agreement to be implemented by the remaining parties, including Iran.

Throughout some of its first year, the Trump Administration indicated support for the agreement. On February 10, 2017, following meetings with the Administration focused on the JCPOA, the EU High Representative for Foreign Policy, Frederica Mogherini, stated that Administration officials "reassured" her that the Administration intended to fully implement the JCPOA (Wroughton, 2017). However, on January 12, 2018, President Trump stated, "the United States will not again waive sanctions" pursuant to the JCPOA absent "our European allies' agreement to fix the terrible flaws of the Iran nuclear deal" (Trump, 2018: https://www.whitehouse.gov/briefings-statements/statement-president-iran-nuclear-deal/). A few months later, on May 8, President Trump, noting that the two sides had been unable to reach an agreement, announced that the United States would no longer participate in the JCPOA and would re-impose sanctions that had been suspended pursuant to the JCPOA (Presidential Memoranda, 2018). President Trump ordered Secretary of State Pompeo to "take all appropriate steps to cease the participation of the United States in the JCPOA," and, along with Secretary of the Treasury Steven Mnuchin, immediately "begin taking steps to re-impose all United States sanctions lifted or waived in connection" with the agreement (Ibid.). The United States has notified the other P5+1 states that the United States will no longer attend meetings of the joint commission, the working group concerning the Arak reactor, and the procurement-working group (Kerr, Katzman, 2018: 23).

The US exit from the JCPOA attracted broad criticism among the other parties of the agreement, and the remaining of the P5+1 states immediately reiterated their support for the JCPOA, announcing their intentions to fulfill their commitments and protect their companies from the effects of any US-imposed sanctions. In a joint statement, France, Germany, and the United Kingdom declared their intention to remain a party to the JCPOA and to "work with all the 
remaining parties" to the deal to ensure that Iran continues to receive "the continuing economic benefits ... linked to the agreement" (Kerr, Katzman, 2018: 25). EU High Representative Mogherini stated that, if "Iran continues to implement its nuclear-related commitments ... the European Union will remain committed to the continued full and effective implementation" of the agreement (Joint Statement from Prime Minister Theresa May, Chancellor Angela Merkel and President Emmanuel Macron Following President Trump's Statement on Iran, 2018).

Therefore, it looks that the divide between Europe and the US is set to deepen over Iran, as long as the Trump Administration's heated rhetoric and actions will continue. The EU made it clear that it will continue to support the JCPOA. Furthermore, the European leaders understood that a constructive relationship between Iran and the EU is essential for the latter, and it could help to achieve its common security and defense objectives while safeguarding its commercial and energy interests.

The theoretical framework of the scientific approach focuses on the paradigm of neorealism and neoliberal institutionalism, which will be used as methodological tools of argumentation, comparison, and analysis of the process of nuclear and economic negotiations.

The basic tenants of neorealism enable the systematic approach to studying shifts in state behavior. Six fundamental neorealist concepts are to be considered when analyzing the behavior of the actors involved in the Iranian file: anarchy, structure, capability, the distribution of power, polarity and national interest. Out of these six concepts, national interest is the one capturing most of the attention when discussing the reasons behind the American administration's decision to exit the JCPOA. In striving for security, states seek to expand their capabilities in relation with the rival states. Thus ensuring territorial, economic and military security constitutes the national interest calculus of a state. At the same time, the level of capability a state possesses vis-à-vis others, constraints or equips states to pursue such interests are driven by its level of capability (Telhami, 2003: 109). Capability, distribution of power and polarity are related to the regional role of Iran and the balance of power in the Gulf region. Thru this concepts it can be explain why the whole process of keeping in place vs. tearing the agreement down, is not only about nuclear deterrence, is also about the geopolitical role of Iran. Beyond the rhetoric regarding the "nuclearization", there is more of the US concern - fuelled by the Israeli and Saudi governments - regarding Tehran's hegemonic ambitions in the region. 
The debate between neorealism and neoliberal institutionalism has dominated IR debate for decades. The two schools of thought have jostled overviews of the international system in an attempt to define the world of international politics. These two paradigms have been important to defining policymaking and the research within international relations (Lamy, 2005: 207). The debate is characterized by their disagreement over specific issues such as the nature and consequences of anarchy, international cooperation, relative versus absolute gains, intentions versus capabilities, institutions, regimes, and priority of state goals. Where neorealists were seen to focus on security measures, neoliberal institutionalists are believed to have placed greater emphasis on environmental and economic issues, with a specific focus on the latter. Keohane and Nye (2001) argue that interdependence, particularly economic interdependence, is now an important feature of world politics. Furthermore, Keohane and Nye argue that states are dominant actors in international relations; equally, there is an assumption that hierarchy exists within international politics and force can be used as an effective instrument of policy. Globalization represents an increase in interconnectedness and linkages; this mutual interdependence between states positively affects behavioral patterns and changes the way states cooperate (Keohane and Nye, 2001). Withdrawing from a theoretical approach of neorealism, the cons camp behavior regarding the JCPOA it is quite easy to be explained. States are assumed at a minimum to want to ensure their own survival, as this is a prerequisite to pursue other goals. This driving force of survival is based in the development of offensive military capabilities for foreign interventionism and as a mean to increase their relative power. Because states can never be certain of other states' future intentions, there is a lack of trust between states which requires them to be on guard at all the time. Given the fact that the JCPOA was built, agreed and sign on lack of trust on both sides P5 countries group and Iran - neorealism seems to fit very well in this sensitive file. Where survival within the anarchic international system is paramount for the realists, cooperation is more likely to be assumed by liberalists. Neoliberal institutionalism it is defined as the principal view on the role that international institutions ought to have in international relations among states, both economically and politically. Its main purpose is to serve as a mediator to find solutions to interstate issues. The European camp, the pro nuclear agreement one, extracts its ideology from this paradigm. EU is willing to look for political and economic cooperation, using this tools to also implement its global strategy. For European decision-makers, the JCPOA could become the mean 
in reaching EU's international agenda, and an opportunity to assert its global role as an honest and trustable partner.

The map of concepts drew within this article is quite wide, and while some of them are pretty known and even used in day-to-day language, some of them belong particularly to the diplomatic discourse, or to the political one. Constructive engagement is seen as a foreign policy strategy intended to seek and maintain a dialogue with anathematized or authoritarian regimes. Since constructive engagement still holds a rather elusive status in international relations literature, it is vital to clarify the idea behind it. Constructive engagement constitutes a non-coercive strategy and set of diplomatic practices for bringing "outlaw" or "rogue" states to conform to what are held by the Great Powers to be legitimate international norms. Its underlying goal is avoidance of conflict, reduction of tension, re-socialization into international society through non-coercive means (George, 1993: 50).

The new Global Strategy focus on security issues reinforces a widespread perception that the EU is experiencing a shift from a transformative-liberal power to a realpolitik actor. However, the familiar framing of "interests versus values" (Youngs, 2016) somewhat distorts EU foreign policy debates. The relationship between values and interests is complex, and sometimes there will be a trade-off between the two, while other times certain values can enhance self-interests, further complicating the process of arriving at a definition for what is a value as opposed to an interest. The Iranian file represents both the means and the aspiration of European foreign policy.

This article uses the negotiation process and its final outcome - international agreements - as a prism to interpret the potential geopolitical role of the Iranian nuclear deal. Moreover, states are considered as the main actors at play, as realism's fingerprints are all over the JCPOA. In addition to discourse analyze, which has been used as analytical method for this article, qualitative research methods, such as content analysis, is used. Apart from the qualitative research of primary and secondary literature, different databases, country reports, and annually updated country profiles were used as well.

Without proposing an exhaustive treatment of this sensitive issue, as long as the events are ongoing and the European leaders (along with their Russians and Chinese counterparts) are looking for the best options to keep the nuclear agreement in place, this article seeks to shed some light over the EU-US relations regarding the Iranian file and to assess how and whether the JCPOA could become the reason of a European-American cleavage. 


\section{Assessing the Iranian Deal in the Light of European Interests}

Relations between Europe and Iran have a long history and have often been characterized by stumbling blocks in the political and diplomatic process of rapprochement since the Islamic revolution from 1979. Trust has been a political capital failing, in both parties' perceptions, to be adequately built and strengthened. And yet, engagement, either critical, constructive or dual track diplomacy has never ceased to see both sides deeply involved in some sort of diplomatic relations (Santini, 2010: 467). The challenge for the EU policymakers is to devise strategies and policies that will build trust and confidence with Tehran and avoid a further downward spiral of relations while increasing European leverage that could be used to alter the cost-benefit analysis, decisionmaking, and behavior of the Iranian regime. A constructive relationship between the EU and Iran is essential for the former, not least to achieve its common security and defense objectives while safeguarding its commercial and energy interests. As it seems to remain the only Western entity willing to deal with Iran, a constructive engagement toward Iran can offer to the EU leverage over Iran, leverage that can be used to prevent the latter from obtaining nuclear weapons, as well as to ensure that if it goes nuclear, Tehran will act rationally. The EU has yet to develop a unified, independent and long-term strategy vis-à-vis Iran, a strategy that would enable it to maintain a constructive relationship with Tehran and achieve its strategic objectives without compromising its core values. For the past decade, the EU made a conscious choice to condition progress in relation with Iran on a single issue: ensuring that the country's nuclear program is of an exclusively peaceful nature. The nuclear agreement with Iran, signed on July 14, 2015, presents Europe with an opportunity to move beyond its exclusive nuclear focus and shift to a relationship based on engagement, not containment. This would allow the EU to pursue its interests with Tehran across a range of issues, such as energy and trade, de-escalating conflicts in the Middle East in which Iran is involved, in environmental and sustainability issues or combatting the drug trade in Afghanistan.

The signing of the JCPOA has set the stage for subsequent cooperation between Iran and the international community. However, maintaining cooperation is often an even more delicate and complicated endeavor that establishing it. Because it is a process of creating joints and gains, cooperation is only possible if parties are willing to reciprocate. Reciprocity, however, should not be expected to produce immediate returns. Parties reciprocate because they are interested in developing relations based on trust and the expectation that, within the future, the other party will 
reciprocate when necessary. Thus, the expectation of future reciprocal behavior becomes an essential component of the ongoing relationship (Hopmann, 2010: 95-110). The JCPOA could open the door to a more mutually beneficial rapport between Iran and the West. With the opportunity present, the challenge remains to make use of it, and it looks like the European decision-makers understood very well this aspect, planning to fully use this opportunity. The gradual and coordinated dismantling of sanctions called for by German Chancellor Angela Merkel and Federica Mogherini's most recent statements could represent an opportunity to test the willingness of both sides to cooperate.

The EU facilitation was pivotal for the achievement of the JCPOA. One day after announcing the deal with the Iranian Foreign Minister Javad Zarif, the High Representative for Foreign Affairs and Security Policy Federica Mogherini issued a statement stressing that "the Iranian nuclear deal has been reached thanks to the facilitation of the EU...with courage, the international community has made a historical step toward peace. With pride, I can say the European Union made it possible" (2015). Mogherini, who won global praise for her role as a mediator, was able to uphold and promote good relations with Iran - which were established by her predecessor, Catherine Ashton - and by chairing the meetings, setting agenda and driving the process she was "putting oil on the wheels of the deal and pushing negotiators to come up with something solid" (de la Baume, 2015). Therefore, a window of opportunity has opened up for Iran and the EU, and there is no secret that intense lobby by large EU companies - such as Siemens, Daimler-Benz or Bayer - leveraged the negotiations. The lifting of the sanctions was beneficial not only for Iran but also for the many EU companies that were eager to exports their goods to a market of nearly 80 million people.

Given all these aspects, on July 15, 2015, Federica Mogherini convened a behind-closed-doors meeting of EU policy-makers and ask that the EU immediately start high-level talks with Iran on energy issues. During this meeting Mogherini, asked the EU Commission to "provide support for preparing the resumption of economic and trade relations with Iran following the lifting of the international sanctions, once the agreement [has] entered into force" (Reuters, 2015). Mogherini also proposed "an official visit to Iran by several members of the Commission (...) to discuss a number of subjects of common interest with the Iranian authorities, such as trade, research, energy and culture" (Ibid.). Moreover, at her press conference in Vienna, the High Representative emphasized that, with the nuclear agreement signed after a decade of tenuous talks, the EU should 
strive to create a broader network of key actors in the Middle East, including Iran, "to see if some forms of regional cooperation is possible" (Norman, 2015, WSJ). At the time, due to the strong European determination to re-launch the ties with Iran, some observers agreed, "there is definitely an assumption in Brussels that any deal will lead to a greater cooperation with Iran" (Ibid.). Also, some analysts have already pointed out that the EU could use the moment to reestablish a framework of energy, trade, economic and geopolitical ties that existed during Mohammad Khatami's presidency but have since dissolved (Ibid.)

One of Europe's strategic concerns in the region - and probably the most important - is energy security. Iran's neighborhood provides the source and access routes for a large part of Europe's energy supplies, and this will be undermined if regional instability grows. Europe's energy imports have already been dealt a blow by the Libyan civil war, and complicated by the standoff with Russia over Ukraine. Iran used to be Europe's sixth most important supplier of energy. Given its geographical location and the fact that Iran has the world's second largest fossil energy resources, it has the potential to become the most important supplier of energy to Europe, as well as the most economic transit route between the oil-rich Caspian Sea states and Europe. Before the JCPOA, due to the political turmoil created by the international concern over the Iranian nuclear program, the European energy firms have been pulling out of Iran, and the EU sanctions prohibited any further investments in the Iranian energy sector ${ }^{1}$. Keeping closer trade and energy ties with Iran will help the EU to address other critical issues. For example, equitable economic growth is essential for fostering political stability in the entire region, and this might marginalize those extremist forces that benefit from poor economic conditions, unemployment and underdevelopment. The promotion of a win-win scenario in regional relations through expansion of energy interconnectivity - through pipelines and electricity grids - and cross-border energy projects (such as investments in refineries that receive their feed from neighboring markets) will definitely be a win for international players. Besides the gain in regional cohesion and interdependence, the European companies can benefit as technology providers and commercial partners in this development.

\footnotetext{
${ }^{1}$ EU sanctions were adopted on July 26, 2010. The sanctions do not, however, prohibit the purchase of oil and gas. See https://www.lexology.com/library/detail.aspx?g=889f7d87-.
} 
The EU could take advantage of the opening toward Iran and propose Tehran an energy cooperation agreement. Europe would have great leverage in this deal since Iran is in dire need of Western technology to help it to efficiently explore and export its vast oil and gas revenues. While Chinese and Russian technologies have been unable yet to match Europe's energy know-how, the EU is likely to find Iran eager to collaborate on energy ties. The European Commission has made similar energy cooperation arrangements with other resource-rich countries, and by negotiating such an agreement with Tehran, the EU could highlight the need for stability in Iran's neighborhood, reducing so the risk and encouraging the European investors. Once as actual energy partnership would be in place, it would secure Europe's energy demands and serve its goal for diversifying oil and gas imports, as well as provide it with a share in Iran's emerging market and enhance protection for European investors (Geranmayeh, 2015: 6). This would also have potentially geopolitical ramifications. The option of exporting its surplus gas supplies would facilitate quicker economic development in Iran, after suffering under the sanctions regime. The fact that the existing pipelines cannot meet Europe's growing demand for gas may represent an opportunity after all. The initial transport of gas to the EU by ship might serve as a cornerstone in reinforcing the trust between parties, albeit to a lesser extent than a pipeline would, not only in terms of maintaining a steady exchange of goods, but also upholding the terms of the JCPOA agreement.

While trade might be not the most critical component of the EU-Iran relationship, it is still important and does affect the EU member states' political decision-making. The EU has been Iran's number one trading partner over a decade, accounting for almost a third of its exports. In 2008, EU exports to Iran totaled 14.1 billion euro, while EU imports from Iran totaled 11.3 billion euro. EU imports from Iran are $90 \%$ in energy and energy-related products. EU exports to Iran in 2008 were mainly in machinery and transport equipment (54.6\%), manufactured goods (16.9\%) and chemicals $(12.1 \%)^{2}$.

The environmental and sustainability issues could be another link for the EU-Iran cooperation. Iran has been suffering from deteriorating environmental conditions and the water supply in various parts of the country is not replenished in a stable and satisfactory manner due to more unstable weather with unpredictable rainfall as well as unsustainable consumption and waste

\footnotetext{
${ }^{2}$ European Commission: http://trade.ec.europa.eu/doclib/docs/2006/september/tradoc 113392.pdf.
} 
of groundwater (Madani, 2014: 315-328). Environmentally sustainable development and water management are areas where EU institutions and industries are at the forefront in terms of capacity building, technology and know-how (Parsi and Esfandiary, 2016: 17).

Due to the fact that Iran is a major transit and consumer for opiate-based drugs from Afghanistan ${ }^{3}$, it would be unwise for the EU to not cooperate with the Iranian authorities to contain the drug trade phenomenon, especially because the EU is one of the major markets for these drugs. The EU, as well as individual member states, has had various kind of cooperation and support for Iranian authorities combatting drug addiction and trade. Over time, the Iranian use of the death penalty to punish drug traffickers has generated huge criticism from human rights organizations and the EU has a long-standing policy of opposing capital punishment. Therefore, the EU could make an effort to convince Iranian counterparts that greater transparency on this issue would be helpful for enhancing cooperation in combating trafficking and drug use and the joints efforts are required for this matter.

Given its strategic position in the Middle East, Iran is also a major regional player, albeit a relatively isolated one. Iran is heavily involved in Iraq, Syria, Lebanon, and Yemen, and also used to spearhead the fight against ISIS, through its Hashd-Al Shabi, Shia militias and material support for the Iraqi army. Therefore, it is in the best interest of the EU that the Middle East be stable. The spread of sectarianism and violent religiously inspired extremism has plagued the Middle East for several decades, and this extremism also spread to groups living in the EU, adding to a dangerous element to an already difficult and complex fight against violent subversive groups across Europe. Keeping closer ties with Iran, in order to consolidate the entries' region economic development will also help the EU to address this critical issue because an equitable economic development is essential for fostering political stability. This will, in turn, marginalize those extremist forces that benefit from poor economic conditions, unemployment, and underdevelopment. The EU's mediation could pave the way to the negotiations of a new Middle East regional security framework.

By capitalizing on its reputation as a "civilian power" (Magri and Perteghella, 2015: 118), EU should work with the US to facilitate regional dialogue, and, eventually, bring Iran and Saudi

\footnotetext{
${ }^{3}$ For an overview of the drug trade in Iran see UNODC Iran fact sheet (Paris Pact): https://www.parispact.net/upload/e20e615974dd55f94302f60fce36e 05d.pdf.
} 
Arabia at the negotiating table with the aim of promoting a new regional security architecture. Notwithstanding the prevalence of contentious issues in which interests differ, it is important to at least kick-start a frank dialogue on realistic options for de-escalation. In order to do so, the EU needs to fine some sort of unity of purpose. Europeans spent much of 2017 trying to convince the trump administration to keep the JCPOA intact, but at this point, Trump's policy trajectory on the nuclear deal seems to be at odds with European interests. There is also a potential risk that the current exchange of words will create a spiral of extremist dialogue between Washington and Tehran leading to escalations in the Middle East. Given the current uncertainty that's surrounding the nuclear deal, European leaders should prepare for and seek to minimize the consequences of further deterioration of relations between Iran and the US.

Given Trump's administration lack of certainty regarding the JCPOA, the European governments will need to prepare for continual battles with Washington over how the deal is implemented. European actors will also need to be far more proactive in fixing the existing problems in the deal. Under Trump, the US government will be far less flexible and cooperative in resolving the banking and financial problems currently facing European companies. European governments and EU regulators will need to take a greater lead in tackling these constraints, including allowing the European Investment Bank to be a provider of financing to European companies undertaking legitimate investments in Iran. European governments should also reinforce existing coordination over contingency plans if the US obstructs the nuclear deal. The EU and E3 should assume leadership of a political initiative that, together with Russia and China, offers Iran enticements to continue to abide by the core elements of the current deal (Geranmayeh, 2017: 8-9). Essentially, Iran should be expected to maintain the critical restrictions and inspections on its nuclear program in return for an economic assistance package offered by the remaining parties to the JCPOA. This contingency plan needs to be communicated clearly to reassure European companies and signal to the US that Europe is serious about its commitment to the deal (Ibid).

While defending the JCPOA, Europe should not lose sight of pursuing the opening created by the nuclear deal to test diplomacy with Iran in other areas where it is urgently required. After four years of gradual engagement between Iran and Europe, it is time to address some of the more contentious issues. The E3 have both the capacity and a strong stake in leading this European effort. European leaders should communicate clearly to both Washington and Tehran a serious 
intent to begin diplomatic talks beyond the nuclear issue (Geranmayeh, 2017: 10-11). The position of the Trump administration on Iran poses a considerable challenge to this effort; however, it is still possible for Europe to push for meaningful diplomacy with Iran in some limited but significant areas, such as freedom of navigation in the Persian Gulf, the Yemen humanitarian crisis or the Syrian civil war.

More likely the Trump administration will increasingly pressure the EU to limit its engagements with Iran. In response, Tehran is likely to seek to widen existing divisions between Europe and the US over the nuclear deal. European governments will need to resist both sides and instead maintain good relations with both Washington and Tehran. Europe's distinct role in helping to de-escalate political crises in the Middle East hinges on its ability to engage with all relevant powers, including Tehran, Riyadh, and Washington. At a time when unpredictability and conflict in the Middle East are at a peak and when Iran-US relations have deteriorated, Europeans should seek to nurture channels of engagement that they have developed with various branches of the Iranian leadership and across the US government. European countries and the EU should use these channels to help counterbalance the impact of Trump's dangerous narratives on regional developments. A symbolic but significant step towards countering the Trump administration's containment policy would be for more European heads of state and governments to visit Iran (Geranmayeh, 2017: 10).

A more normal relationship between Europe and Iran would allow cooperation and competition to coexist across different areas. This would put Europe in a better position to encourage all regional stakeholders, including Iran and the Gulf Cooperation Council states, to take ownership of de-escalating conflicts in their neighborhood in ways that are increasingly necessary and yet still glaringly absent. This would lay the groundwork for a European-supported regional settlement to which all key regional stakeholders are partners - even if this settlement cannot be achieved for a long time. To reach this stage, Europe will need to create a formal political structure and establish organizational support to take forward its engagement with Iran. Europe's expectations from Iran should take into consideration the geopolitical realities and Iran's priorities. Under existing conditions, Tehran will not be persuaded to overhaul its regional security strategy or to withdraw the support given to some local actors such as Hezbollah. Neither will more intense engagement result in a new regional alliance between Europe and Iran. Europe should not disregard the grave scale of problems faced by both sides in the region, so its relationship with 
Iran should go beyond merely ad hoc cooperation on areas of common interest. While time and confidence building are required to reach a more normalized stance, Europe now has the political space to engage with Iran on more contentious issues - even if progress advances at a slow rate (Geranmayeh, 2015: 9-10).

The JCPOA gives policymakers the liberty to step out of the nuclear-centric vision on Iran and to highlight areas in which Europe can benefit from engaging with Tehran, notably on regional security. Difficult though it may be, to make the greatest contribution towards establishing regional order, Europe should distance itself from taking sides in regional struggles and allow for maximum flexibility in policy choices by considering the option of actively dealing with Iran where this best serves European security (Ibid.). Europe now has the capacity to take on a more ambitious and critically important role in recalibrating regional security approaches after the nuclear deal.

\section{EU-US: A Coming Clash over the Iranian File?}

John Limbert is an American diplomat who has gone through one of the darkest pages of the US-Iran relations, the hostage crisis. However, he still believes in the rapprochement between the "Great Satan and the Mad Mullahs" (2005: 49, 69). Limbert wrote: "Under the right conditions, with balanced judgments and sound negotiating strategy, we can still reach an understanding that suits the interests of both sides. Most important, we do not have to be friends to do so. After all, if Americans and Iranians could never agree on anything, then today I and my embassy colleagues would probably still captives in Tehran" (Limbert, 2009: 6). And yet it took 35 years of diplomatic estrangement and almost 13 years of failed negotiations over Iran's contested nuclear program to get to the agreement signed on July 14, 2015. It was the chance that the Hassan Rouhani and Barack Obama's presidencies overlapped, and the professed intention of the latter to initiate an ambitious reassessment of the Middle East policy, combined with the moderate policy proposed by Rouhani, led to a shy warming of relations between Washington and Tehran. However, while triggering vocal criticism from America's traditional allies in the region - especially from Israel, already nervous about the potential consequences of normalization of relations between Iran and US - the nuclear deal fuelled hopes among the supporters of a new season in US Middle East policy. Yet, under the new American administration, the honeymoon between Washington and Tehran seems to be short-lived.

Donald Trump expressed his intentions to shift the US policy on Iran toward aggressive containment and away from the diplomatic openings created by his predecessor. The primary focus 
of this shift is the Joint Comprehensive Plan of Action, which Trump called an "embarrassment and disastrous" ${ }^{\prime}$. On May $8^{\text {th }}, 2018$, president Trump announced that the US is set to leave the Iran nuclear deal, even if all the European leaders tried to convince out the American president to not do so. After few month of speculation and a flurry of last-minute European diplomacy, Donald Trump has taken perhaps the most consequential decision of his unconventional presidency with the announcement that he is re-imposing US sanctions on Iran in a deliberately provocative breach of the 2015 nuclear agreement with Iran. By torpedoing US adherence to the accord Trump has all but guaranteed its collapse, a move that opens the door to the unfettered resumption of Iran's nuclear program and unleashes unpredictable escalatory pressures in an already volatile Middle East. Even more, the French Foreign Minister reportedly described the deal as being a warranty for peace, and France and Germany vowed to respect the agreement, while British Foreign Secretary, Boris Johnson, in Washington on May $7^{\text {th }}$, 2018, stated that as far as he knows, the American administration has no clear Plan B for what to do next.

Is not news that Donald Trump is not easy to get along with. On many global security issues, Europeans take very different approaches than the new American president. But perhaps nowhere is the difference more profound than on the question of Iran. Given the president's harsh rhetoric and his recent efforts to put that talk into practice, a transatlantic clash on the issue seems almost inevitable. European countries should prepare now to minimize the damage and preserve their strategic interests on non-proliferation and the pursuit of stability in the Middle East. The divide between Europe and the US is set to deepen over Iran. The Trump administration's heated rhetoric and recent actions indicate US strategy is exclusively focused on isolating and containing Iran. The ramifications of US policy go beyond damaging the non-proliferation architecture Europe has helped build. It could lead to even greater instability in the Middle East and severely limit diplomacy with Iran to resolve regional issues. The current trajectory not only endangers European non-proliferation goals, but it also heightens the risk of a nuclear arms race and further military escalation in Europe's backyard. Direct or indirect, a confrontation between American and Iranianbacked forces across the Middle East will further fuel the regional conflicts, particularly in Iraq and Syria, that have already imposed heavy costs on Europe (Geranmayeh, 2017: 1-2). 4 *** (2017) Remarks by President Trump on Iran Strategy, October 13, https://www.whitehouse.gov/briefings-
statements/remarks-president-trump-iran-strategy/. 
President Trump did not waste any opportunity to broadcast his animosity toward Iran. He has called for the country's international isolation and sought to pressure foreign companies not to do business with the country. Moreover, the influence of the Israeli Prime Minister, Benjamin Netanyahu, over the American president is not to be neglected. The recent show put up by Netanyahu, within he stated that Israel has strong evidence of the continuation of the Iranian nuclear program, evidence which actually never been made public, being exposed only at the level of rhetoric. What is interesting to underline is that Netanyahu's recent allegations about Iran are not his first endeavor to influence the American administrations' on Middle East foreign policy lines. In 2002 he stated in front of the American Congress that Israel has indubitable evidence about Iraq's nuclear weapons program. One year later, George W. Bush decided to invade Iraq, and yet, no trace of nuclear capabilities has been found.

The premeditated American dismantling of an agreement that was the product of more than a decade of intense diplomacy and economic pressure marks a staggeringly counterproductive step. That it was undertaken over the vocal objections of Washington's closest allies and without a clear strategy of mitigating the newly heightened risks of Iranian proliferation and conventional retaliation represent an abdication of American leadership on the international stage that is unparalleled in recent history (Maloney, 2018). Trump's decision might weaken even the American security while breaking Washington's credibility on the international stage. Also, it isolates the US from its European allies, puts Israel at risk, empowers Iran's hardliners and reduces the global leverage to address Tehran's misbehavior, while damaging the ability of future American administrations to make international agreements. Donald Trump and his newly reconstituted foreign policy and national security team are not only highly suspect of organic reform in Iran; they have become hell-bent on regime change in Tehran. Ripping-up the JCPOA deal makes this policy choice clear. In 2018, Iran and America are entering a new phase of their ever-strained relationship and it seems never to work out for the best.

Shortly after Donald Trump's public statement, Federica Mogherini issued a statement regarding the EU's Iran strategy and assessing the JCPOA as being "a key element of global nuclear non-proliferation architecture" (Mogherini, 2018). Also, she reassured Tehran that as long as "Iran continues to implement its nuclear-related commitments, as it is doing so far, the European Union will remain committed to the continued full and effective implementation of the nuclear deal" (Ibid.). Trump's decision to withdraw the US from the Iranian nuclear deal has triggered a 
new environment of unpredictability in the Middle East and the European governments will need to prepare for what it might come next. The EU member states will also need to be far more proactive in fixing the existing problems in the deal and to do their best to preserve it, also to assume leadership of a political initiative that, together with Russia and China can offer Iran the incentives to continue to abide by the core elements of the current deal. Also, in defiance of US President, the European leaders began drawing up plans to preserve the JCPOA. Just a few hours after Trump's announcement, British Prime Minister Theresa may, German Chancellor Angela Merkel and French President Emmanuel Macron published a joint statement in which they expressed their commitment to the nuclear agreement, which they described as very important for the international security. As part of the efforts to salvage the deal, foreign ministers from the United Kingdom, France, and Germany are expected to meet in London with the Iranian counterpart. Also, Russia and China have also reaffirmed their commitment to the JCPOA, but to convince Iran to stick with the deal, the Europeans will need to demonstrate that they still can deliver most of the economic benefits that Tehran was promised in exchange for giving up its nuclear weapons program and allowing a robust system of international inspections.

Although European capitals share some of the US concerns about Iran, Europe is quickly parting ways with the Trump administration over two fundamental issues. First, they disagree on what they are trying to achieve with Iran. Trump's statements on Iran move US policy aims towards efforts to weaken the Islamic Republic and perhaps to the idea of regime change. The former US secretary of state, Rex Tillerson, for example, effectively backed a regime change approach when he outlined that the administration would "work towards support of those elements inside of Iran that would lead to a peaceful transition of that government" (Tillerson, 2017). The second source of European-US differences over Iran relates to the tools used to achieve these goals. European governments are moving away from isolating Iran using containment and sanctions towards engaging the country using diplomatic and economic tools. The Trump administration has moved in the opposite direction, seeking to isolate Iran through political measures and tougher sanctions. Perhaps the clearest example of this division occurred in May 2017. During Trump's visit to Riyadh, he called for all nations to isolate Iran. Within hours, the EU High Representative together with other European leaders publicly congratulated the re-elected president, Hassan Rouhani, on his victory and expressed hope for further political opening with Iran (Bolongaro, 2017). Similarly, on the same day as Trump made his speech on the new US Iran strategy, the 
French president discussed with Rouhani a potential trip to Iran, which would be the first by a French head of state since Iran's 1979 revolution. In parallel, a number of giant European companies have ignored Trump's calls to refrain from doing business with Iran and instead announced new deals with their Iranian counterparts.

While there were no concrete steps immediately agreed upon, the refusal of European allies to accept Trump's decision was likely to draw the president ire. Also, some analysts and EU officials and diplomats questioned why North Korea would ever agree to a deal with Donald Trump to limit its own nuclear weapons program given that Washington was not necessarily committed to its international agreements from one administration to the next. Nevertheless, the decision to withdraw the US from the JCPOA demonstrates that Washington has decided that confrontation with Iran is both necessary and inevitable, regardless of what European allies think (Herszenhorn, de la Baume, Vinocur, 2018).

In sum, the European leaders are determined to try to salvage (Dehghan, Boffey, 2018) the Iran nuclear deal even though this potentially puts them on a collision course with an uncompromising US President, determined to confront Iran as the "leading state sponsor of terror" (Borger, Dehghan and Holmes, 2018). The coming clash represents a huge test of durability of the surprisingly concerted alliance that Germany, France and the United Kingdom have managed to maintain in their humiliatingly fruitless bid to prevent Donald Trump from explicitly withdrawing from the deal signed by his predecessor Barack Obama.

\section{Conclusions}

What the EU and Iran need is a strategic and structured dialogue. Strategic here means that it must reach beyond the list of specific (usually contentious) issues, look at the larger picture and set more long-term goals for what kind of relationship the two parties want to have. Structured, in that it is underpinned by regular interaction on civil servant and technical levels dealing with a variety of sectors; thus, establishing an institutionalized process for pursuing a variety of solutions and exchanges.

As unpredictable as seems to be, this situation, however, might be a gift for the EU to prove itself as a global leader. The EU-Iran dialogue should be maintained, and also extended beyond the common concerns in the Middle East. Both the nuclear issue and regional turmoil highlighted that for the EU not to have a functioning relationship with Iran is politically very costly. Iran is too 
big and too important of a regional actor for it to be ignored: the EU must engage with Tehran and make it a stakeholder for regional dialogue and stability to occur. Iran has its own policy objectives in much the same way as any other state. It is not always responsible in ways that we would like it to be, nor does it always make calculations of what is prudent policy in ways we can comprehend. In essence, Iran may not be an indispensable interlocutor, but it is in many regards an unavoidable one: the cost for the EU to pursue its policies vis-à-vis the region will be much higher and less effective with Iran absent from the table. Neither does the absence of an EU-Iran relationship mean that such a relationship void will remain empty. If Europe is not present on the Iranian scene, be it in trade or politics, other actors (China, Japan, India etc.) will claim that space. As a result, in order for the EU to make any headway in addressing issues of concern and build a more stable relationship with Iran, the EU must devise a medium to long-term strategy for regular, sustained dialogue with Iran. In other words, the EU must have a clear notion of what a structured and strategic relationship with Iran can and should look like. Such a rethink is not about rewarding or punishing the Islamic Republic of Iran, but rather, about the role and position of the EU in the Middle East in general and how it can pursue its interests most effectively.

However, out there is the risk that the unity forged by European trio (France, Germany and the UK) over the need to preserve the deal bow falters as disagreements surface on how far are prepared to antagonize a determined US president, not to mention Israel and Saudi Arabia, to keep the deal alive. Also, the viability of Europe's plans to keep Iran committed to the deal will depend on how aggressively the US Treasury ensures that any economic sanctions it now imposes on US firms that continue to trade with the central bank of Iran also impact on European firms. The first sanction that is being re-imposed by Trump, as a result of ending the waiver, is a requirement for firms to show they are significantly reducing the number of oil deals they are striking with Iran via the country's central bank. That will take as long as 180 days to measure. But in an uncompromising mood, Trump implied other much wider sanctions would also be re-imposed, even though he gave no timeframe for doing so.

Europeans spent much of 2017 trying to convince the Trump administration to keep the JCPOA intact. But at this point, Trump's policy trajectory on the nuclear deal is clearly at odds with European interests. The EU and leading European member states need to see beyond the security crises in their immediate neighborhood and take the lead in pursuing the strict implementation of the JCPOA, engaging Iran in regional cooperation, and strengthening global nonproliferation. 
Without the US, Iran is unlikely to accept all the obligations outlined in the JCPOA. However, keeping Iran on board with the JCPOA's material restrictions is likely to limit Iran's ability to expand its nuclear program. This, in turn, will reduce the possibility of military strikes against Iranian nuclear facilities by Israel or the US.

However, there is a possibility that, despite sustained diplomatic efforts, the EU cannot maintain the nuclear agreement. Reportedly, the Iranian President Hassan Rouhani told French President Emmanuel Macron, in a phone conversation, that Europe has "under the current conditions, a very limited opportunity to preserve the nuclear deal, and must, as quickly as possible, clarify its position and specify and announce its intentions with regard to its obligations."5

The JCPOA has opened a new chapter in EU-Iran relations and Europe should do its best to take advantage of it. Beyond the economic advantages, especially energy security, the EU has a unique chance to prove its capacity to play as a major global actor. Europeans need to begin a deep conversation among themselves and with Iran on the future of their relationship and to explore ways that Europe can contribute toward order in a fractured region on its doorstep. The EU has now the opportunity to take on a more ambitious and critically important role in recalibrating regional security approaches.

\section{References}

1. *** (2018) "Remarks by HR/VP Mogherini on the statement by US President trump regarding the Iran nuclear deal (JCPOA)", May 8 ${ }^{\text {th }}$, 2018. [Online] Available from: https://eeas.europa.eu/headquarters/headquarters-homepage/44238/remarks-highrepresentativevice-president-federica-mogherini-statement-us-president-trump_en [Accessed at 31/07/2018].

2. *** (2015) "EU's Mogherini seeks talks with Iran on energy, trade by early 2016", Reuters, July 31, 2015. [Online] Available from: https://www.reuters.com/article/irannuclear-eu/eus-mogherini-seeks-talks-with-iran-on-energy-trade-by-early-2016idUSL5N10B25R20150731 [Accessed at 31/07/2018].

\footnotetext{
$5 * * *$ (2018), Europe has limited opportunity to preserve nuclear deal, Rouhani tells Macron, May 9, Trend News Agency, https://en.trend.az/iran/nuclearp/2900683.html.
} 
3. *** (2015) "Mogherini proud of EU contribution to Iranian deal", European Union External Action, Brussels, July 15, 2015. [Online] Avaialble from: http://collections.internetmemory.org/haeu/content/20160313172652/http://eeas.europa.e u/top_stories/2015/150715_iran-deal_en.html [Accessed at 31/07/2018].

4. *** (2015) "IAEA Director General's Statement and Road-map for the Clarification of Past and Present Outstanding Issues regarding Iran's Nuclear Programme", July 14, 2015. [Online] Available from: https://www.iaea.org/newscenter/statements/iaeadirector-generals-statement-and-road-map-for-the-clarification-of-past-presentoutstanding-issues-regarding-irans-nuclear-programme [Accessed at 31/07/2018].

5. *** (2017) "Rex Tillerson's testimony to House Foreign Relations committee", June 14, 2017. [Online] Available from: https://www.youtube.com/watch?v=MVWzwAU2DuE [Accessed at 5/08/2018].

6. BEEMAN, W. O. (2005), "The 'Great Satan' vs. the 'Mad Mullahs'. How the United States and Iran Demonize Each Other", London: Praeger.

7. BORGER, J., DEHGHAN, S. K., HOLEMS, O. (2018), "Iran deal: Trump breaks with European allies over 'horible, one-sided' nuclear agreement”, May 9, 2018, The Guardian. [Online] Available from: https://www.theguardian.com/world/2018/may/08/iran-dealtrump-withdraw-us-latest-news-nuclear-agreement [Accessed at 5/08/2018].

8. DE LA BAUME, M. (2015), "The women behind the Iran nuclear deal”, Politico, July 17, 2015. [Online] Available from: https://www.politico.eu/article/the-women-behind-thenuclear-deal/ [Accessed at 27/10/2018].

9. GERANMAYEH, E. (2015), "Engaging with Iran: A European Agenda", European Council on Foreign Relations, July, ECFR(139), pp. 1-12.

10. GERANMAYEH, E. (2017), "The Coming Clash: Why Iran Will Divide Europe from the United States", European Council on Foreign Relations, October, ECFR(236), pp. 1-13.

11. GEORGE, A. (1993), "Bridging the Gap: Theory and Practice in Foreign Policy", Washington D. C.: US Institute for Peace.

12. HOPMANN, P. T. (2010), "Synthesizing Rationalist and Constructivist Perspectives on Negociated Cooperation", in Zartman, I. W. and Touval, S. (eds.), International Cooperation: The Extensions and Limits of International Multilateralism, New York: Cambridge University Press, pp. 95-110. 
13. KATZAMAN, K., KERR, P. K., HEITSHUSEN, V. (2018), “U. S. Decision to Cease Implementing the Iran Nuclear Agreement", Congressional Reasearch Service Report, May 9, 2018, pp. 1-14.

14. KATZAMAN, K., KERR, P. K. (2018), "Iran Nuclear Agreement and U. S. Exit", Congressional Reasearch Service Report, July 20, 2018, pp. 1-38.

15. KEOHANE, R. O., NYE, J. S. (2001), "Power and Interdependence", New York: Longman.

16. LAMY, S. L. (2005),"Contemporary mainstream approaches: neo-realism and neoliberalism" in Bayliss, J., Smith S. (eds.) (2005), The Globalization of World Politics: an introduction to international relations, Oxford: Oxford University Press, pp. 205-225.

17. LIMBERT, J. W. (2009), Negotiating with Iran: Wrestling the Ghosts of History, Washington D. C.: United States Institute of Peace Press.

18. MADANI, K. (2014), "Water management in Iran: what is causing the looming crisis?", Journal of Environmental Studies and Sciences, December, 4(4), pp. 315-328.

19. MAGRI, P., PERTEGHELlA, A. (2015), "Iran After the Deal: The Road Ahead", Milano: ISPI.

20. NICOULLAUD, F. (2016), "Can Iran Deal Survive A US Withdrawal?", LobeLog, November 16, 2016. [Online] Available from: http://lobelog.com/can-the-iran-dealsurvive-a-us-withdrawal/ [Accessed 17/09/2017].

21. NORMAN, L. (2015), "Warming ties with Iran? For EU, It's Complicated", The Wall Street Journal, July 15, 2015. [Online] Available from: https://www.wsj.com/articles/warming-ties-with-iran-for-eu-its-complicated1436992813 [Accessed at 25/08/2018].

22. PARSI, R., ESFANDIARY, D. (2016), “An EU strategy for relations with Iran after the nuclear deal", Brussels: AFET, pp. 1-25.

23. Presidential Memoranda (2018), "Ceasing U. S. Participation in the JCPOA and Taking Additional Action to Counter Iran's Malign Influence and Deny Iran All Path to a Nuclear Weapon", May 8, 2018. [Online] Available from: https://www.whitehouse.gov/presidential-actions/ceasing-u-s-participation-jcpoa-takingadditional-action-counter-irans-malign-influence-deny-iran-paths-nuclear-weapon/ [Accessed at May 9, 2018]. 
24. Press release (2018), “Joint statement from Prime Minister Theresa May, Chancellor Angela Merkel and President Emmanuel Macron following President Trump's statement on Iran", May 8, 2018. [Online] Available from: https://www.gov.uk/government/news/joint-statement-from-prime-minister-maychancellor-merkel-and-president-macron-following-president-trumps-statement-on-iran [Accessed at 09/05/2018].

25. RATHEKE, J., SHAFRON, M. (2018), "On a Mission, Macron and Merkel Come to Washington", Center for Strategic \& International Studies, April 23, 2018. [Online] Available from: https://www.csis.org/analysis/mission-macron-and-merkel-comewashington [Accessed at 25/08/2018].

26. SANTINI, R. H. (2010), "European Union discourses and practices on the Iranian nuclear programme", European Security, 19(3), pp. 467-489.

27. "Statement by the President on the Iran Nuclear Deal", January 12, 2018. [Online] Available from: https://www.whitehouse.gov/briefings-statements/statement-presidentiran-nuclear-deal/ [Accessed at 02/10/2018].

28. SHRIVANI, T, SINIŠA, V. (2015), "After the Iran Nuclear Deal: Europe's Pain and Gain", The Washington Quarterly, 38(3), pp. 79-92.

29. TELHAMI, S. (2003), "An Essay on Neorealism and Foreign Policy” in Hanami, A. K. (ed.) (2003), Perspectives on Structural Realism, New York: Palgrave Macmillan.

30. WROUGHTON, L. (2017), “EU's Mogherini: U. S. says will fully implement Iran nuclear deal", Reuters, February 10, 2017. [Online] Available from: https://www.reuters.com/article/us-usa-trump-eu-idUSKBN15P1XM. [Accessed at 30/03/2018].

31. YOUNGS, R. (2016), "EU Global Strategy: How to Balance Interests and Values", January 15, 2016. [Online] Available from: https://carnegieeurope.eu/2016/01/15/euglobal-strategy-how-to-balance-interests-and-values-pub-62531. [Accessed at 27/10/2018]. 